\title{
ОСОБЛИВОСТІ РЕМОДЕЛЮВАННЯ ВЕНОЗНОГО РУСЛА СІМ'ЯНИКІВ ПРИ ПОСТРЕЗЕКЦІЙНІЙ ЛЕГЕНЕВІЙ АРТЕРІАЛЬНІЙ ГІПЕРТЕНЗІЇ
}

\section{๑С. О. Коноваленко}

Тернопільський національний медичний університет імені І. Я. Горбачевського МОз України

РЕзЮМЕ. Видалення правої або лівої легені може призводити до пострезекційної легеневої артеріальної гіпертензії, венозного застою в органах великого кола кровообігу та структурно-функціональних змін у них. Морфологічні зміни венозного русла сім'яників при пострезекційній легеневій артеріальній гіпертензії вивчені недостатньо.

Мета - вивчити особливості ремоделювання венозного русла сім'яників при пострезекційній легеневій артеріальній гіпертензії.

Матеріал і методи. Морфологічними методами досліджено венозне русло сім'яників 45 лабораторних білих щурів-самців, які були поділені на 3 групи. Артеріальну легеневу гіпертензію та легеневе серце моделювали шляхом виконання у дослідних тварин правосторонньої пульмонектомії. Проводили окреме зважування камер серця та їх планіметрію. На гістологічних мікропрепаратах з сім'яників визначали діаметр закапілярних венул, венул, діаметр зовнішній, діаметр внутрішній венозних судин, висоту ендотеліоцитів венозних судин, діаметр їх ядер, ядерно-цитоплазматичні відношення у цих клітинах, відносні об'єми пошкоджених ендотеліоцитів. Статистичну обробку отриманих даних здійснено в програмі Statistica Soft 13.0.

Результати. Усестороннім аналізом морфометричних параметрів встановлено, що більшість 3 них в умовах змодельованої патології виражено змінювалися. Діаметр закапілярних венул при компенсованому легеневому серці статистично $(p<0,01)$ достовірно збільшився з $(12,82 \pm 0,09)$ мкм до $(13,40 \pm 0,12)$ мкм, тобто на 4,5 \%, а діаметр венул - на 2,3 \% ( $<0,05)$. Аналогічно змінювалися внутрішній та зовнішній діаметри венозних судин. Зовнішній діаметр вказаних венозних структур статистично достовірно ( $<<0,05)$ зріс майже на 3,1 \%, а внутрішній - на 2,8 \% $(p<0,05)$. Висота ендотеліоцитів венозних судин, діаметри їх ядер в умовах компенсованого легеневого серця суттєво не змінювалися. Незмінними при цьому залишалися ядерно-цитоплазматичні відношення в ендотеліоцитах, що свідчило про стабільність клітинного структурного гомеостазу.

Досліджувані морфометричні параметри венозних судин при декомпенсованому легеневому серці змінювалися більш виражено. Так, діаметр закапілярних венул у вказаних експериментальних умовах з вираженою статистично достовірною різницею (р<0,001) збільшився на 19,1\%. Аналогічної структурної перебудови при цьому зазнали також діаметри венул, які зросли з $(26,96 \pm 0,18)$ мкм до $(32,84 \pm 0,21)$ мкм, тобто на $22,2 \%(p<0,001)$. 36ільшеними у даних умовах досліду виявилися також зовнішні та внутрішні діаметри вен. При цьому вказаний зовнішній параметр венозних судин статистично достовірно (р<0,001) зріс на 18,5 \%, а внутрішній діаметр - 22,3 \% $(p<0,001)$. Виявлене ремоделювання венозних судин призводило до стоншання їх стінок. Світлооптично морфологічні зміни структур домінували при декомпенсації легеневого серця.

Висновок. Отримані дані свідчать, що пострезекційна легенева артеріальна гіпертензія призводить до виражених структурних змін у венозному руслі сім'яника, що суттєво порушує дренаж венозної крові від вказаного органа, погіршує його трофічне забезпечення та відіграє важливу роль у патоморфогенезі його ураження. Найвираженішим ступінь ремоделювання венозних судин виявився при декомпенсації легеневого серця.

КлючовІ СлОВА: легенева гіпертензія; сім'яники; венозне русло.

Вступ. В останні роки проблема хронічного легеневого серця набуває важливого значення у зв'язку з інтенсивним збільшенням кількості хронічних обструктивних захворювань легень, хронічних форм туберкульозу та професійних захворювань легень, при яких основною причиною інвалідності та смертності хворих $\epsilon$ хронічне легеневе серце та його декомпенсація. Патогенез хронічного легеневого серця складний та багатогранний, що суттєво ускладнює сучасну діагностику артеріальної легеневої гіпертензії та легеневого серця $[2,9]$. Недостатньо вивчені процеси, що детермінують зміни органного, тканинного та клітинного гомеостазів, ступінь порушення яких визначає компенсацію, субкомпенсацію та декомпенсацію легеневого серця. Важливу роль при цьому відіграє венозне русло органів, через яке відбувається дренаж венозної крові $[1,5]$. Венозне русло сім'яників в умовах компенсованого та декомпенсованого легеневого серця залишається маловивченим.

Мета - вивчити особливості ремоделювання венозного русла сім'яників при пострезекційній легеневій артеріальній гіпертензії.

Матеріал і методи дослідження. Морфологічними методами досліджено венозне русло сім'яників 45 лабораторних білих щурів-самців, які були поділені на 3 групи. 1-а група включала 15 iнтактних дослідних тварин, 2-а - 20 щурів з легеневою артеріальною гіпертензією і компенсованим легеневим серцем, 3-10 дослідних тварин з легеневою артеріальною гіпертензією і декомпенсованим легеневим серцем. Артеріальну легеневу гі- 
Огляди літератури, оригінальні дослідження, погляд на проблему, випадок з практики, короткі повідомлення пертензію та легеневе серце моделювали шляхом виконання у дослідних тварин правосторонньої пульмонектомії [2, 9]. Евтаназію щурів здійснювали кровопусканням в умовах тіопентал-натрієвого наркозу через 3 місяці від початку експерименту. Проводили окреме зважування камер серця та їх планіметрію [3]. 3 сім'яників вирізали шматочки, які після відповідного проведення через етилові спирти зростаючої концентрації поміщали у парафін. Мікротомні зрізи сім'яників товщиною 5-7 мкм після депарафінізації забарвлювали гематоксиліном-еозином, за ван-Гізон, Маллорі, Вейгертом, толуїдиновим синім.

На гістологічних мікропрепаратах сім'яників визначали діаметр закапілярних венул (ДЗВ), венул (ДВ), діаметр зовнішній (ДЗВС), діаметр внутрішній (ДВВС) венозних судин, висоту ендотеліоцитів (ВЕн) венозних судин, діаметр їх ядер (ДяЕн), ядерно-цитоплазматичні відношення у цих клітинах (ЯЦВЕн), відносні об'єми пошкоджених ендотеліоцитів (ВОПЕн) $[3,9]$. Кількісні показники о6робляли статистично у відділі системних статистичних досліджень Тернопільського національногомедичногоуніверситетуімені.Я.Горбачевського МОЗ України. Різницю між порівнюваними морфологічними параметрами визначали за критеріями Манна-Уїтні та Стьюдента [4]. Усі маніпуляції та евтаназію щурів проводили з дотриманням основних принципів роботи з експериментальними тваринами відповідно до положення Європейської конвенції про захист хребетних тварин, які використовуються для експериментальних та інших наукових цілей (Страсбург, 1986 р.), Загальних етичних принципів експериментів на тваринах, ухвалених Першим національним конгресом з біоетики (Київ, 2001 р.), а також Закону України «Про захист тварин від жорстокого поводження" (від 21.02.2006) [7].

Результати й обговорення. Отримані кількісні морфометричні показники представлені у табл. 1.

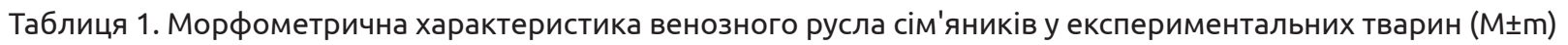

\begin{tabular}{|l|c|c|c|}
\hline \multirow{2}{*}{\multicolumn{1}{c|}{ Показник }} & \multicolumn{3}{|c|}{ Група спостереження } \\
\cline { 2 - 4 } & 1 & 2 & 3 \\
\hline ДЗВ, мКм & $12,82 \pm 0,09$ & $13,40 \pm 0,12^{* *}$ & $32,84 \pm 0,21^{* * *}$ \\
\hline ДВ, МКм & $26,96 \pm 0,18$ & $27,58 \pm 0,15^{*}$ & $47,80 \pm 0,36^{* * *}$ \\
\hline ДЗВС, мКм & $40,32 \pm 0,42$ & $41,56 \pm 0,39^{*}$ & $34,60 \pm 0,24^{* * *}$ \\
\hline ДВВС, мКм & $28,30 \pm 0,24$ & $29,10 \pm 0,21^{*}$ & $4,52 \pm 0,03^{* *}$ \\
\hline ВЕн, мКм & $4,80 \pm 0,03$ & $4,75 \pm 0,04$ & $3,46 \pm 0,02^{* *}$ \\
\hline ДЯЕН, мКм & $3,56 \pm 0,02$ & $3,52 \pm 0,03$ & $0,585 \pm 0,004^{* * *}$ \\
\hline ЯЦВЕн & $0,550 \pm 0,003$ & $0,552 \pm 0,003$ & $38,60 \pm 0,51^{* * *}$ \\
\hline ВОПЕн, \% & $2,20 \pm 0,03$ & $6,48 \pm 0,04^{* * *}$ & \\
\hline
\end{tabular}

Примітка. * $-p<0,05 ; * *-p<0,01 ; * * *-p<0,001$.

Усестороннім аналізом морфометричних параметрів вказаної таблиці встановлено, що більшість з них в умовах змодельованої патології виражено змінювалися. Діаметр закапілярних венул при компенсованому легеневому серці статистично $(p<0,01)$ достовірно збільшився з $(12,82 \pm 0,09)$ мкм до $(13,40 \pm 0,12)$ мкм, тобто на $4,5 \%$, а діаметр венул - на $2,3 \%(p<0,05)$. Аналогічно змінювалися внутрішній та зовнішній діаметри венозних судин. Зовнішній діаметр вказаних венозних структур статистично достовірно $(p<0,05)$ зріс майже на $3,1 \%$, а внутрішній - на $2,8 \%(p<0,05)$. Висота ендотеліоцитів венозних судин, діаметри їх ядер в умовах компенсованого легеневого серця суттєво не змінювалися. Не зміненими при цьому виявилися ядерно-цитоплазматичні відношення в ендотеліоцитах, що свідчило про стабільність клітинного структурного гомеостазу [8, 9].

Відносний об'єм пошкоджених ендотеліоцитів у даних експериментальних умовах статистично достовірно $(p<0,001)$ зріс з $(2,20 \pm 0,03)$ до $(6,48 \pm$
0,04), тобто у 2,9 раза. 36ільшення кількості пошкоджених ендотеліоцитів при цьому деякі автори пояснюють посиленням апоптозу в даних умовах експерименту [5].

У результаті проведених досліджень встановлено, що досліджувані морфометричні параметри венозних судин при декомпенсованому легеневому серці змінювалися більш виражено. Так, діаметр закапілярних венул у вказаних експериментальних умовах з вираженою статистично достовірною різницею $(p<0,001)$ збільшився на $19,1 \%$. Аналогічної структурної перебудови при цьому зазнали також діаметри венул, які зросли з $(26,96 \pm 0,18)$ мкм до $(32,84 \pm 0,21)$ мкм, тобто на $22,2 \%(p<0,001)$.

Збільшеними у даних умовах досліду виявилися також зовнішні та внутрішні діаметри вен. При цьому вказаний зовнішній параметр венозних судин статистично достовірно $(p<0,001)$ зріс на $18,5 \%$, а внутрішній діаметр - на 22,3 \% ( $<<0,001)$. Виявлене ремоделювання венозних судин призводило до стоншання їх стінок. 
Огляди літератури, оригінальні дослідження, погляд на проблему, випадок з практики, короткі повідомлення

При декомпенсації легеневого серця висота ендотеліоцитів венозних судин сім'яників зменшилася з $(4,80 \pm 0,03)$ мкм до $(4,52 \pm 0,03)$ мкм, тобто на 5,8 \% (р<0,01). Діаметри ядер цих клітин також зменшилися на 2,8 \% (р<0,01). Нерівномірні диспропорційні зміни просторових параметрів цитоплазми та ядер ендотеліоцитів венозних судин сім'яників при декомпенсації легеневого серця призводили до порушення співвідношень між ними, що адекватно відображали ядерно-цитоплазматичні відношення. Вказаний морфометричний параметр у даних умовах експерименту з високою статистично достовірною різницею $(p<0,001)$ зріс 3 $(0,550 \pm 0,003)$ до $(0,585 \pm 0,004)$, тобто на 6,4 \%. Виявлене свідчило про виражене порушення структурного клітинного гомеостазу $[3,8]$.

Відносний об'єм пошкоджених ендотеліоцитів венозних судин сім'яників при декомпенсації легеневого серця зріс з $(2,20 \pm 0,03) \%$ до $(38,60 \pm$ $0,51)$ \%. Наведені морфометричні параметри статистично достовірно ( $p<0,001)$ відрізнялися між собою. При цьому останній кількісний морфологічний показник перевищував попередній у 17,5 раза. Ушкодження значної кількості ендотеліоцитів могло призводити до ендотеліальної дисфункції [6], що суттєво впливало на ступінь ремоделювання досліджуваних судин. У змодельованих патологічних умовах у більшості випадків досліджувані структури були розширені, переповнені кров'ю. Спостерігався також перивазальний набряк, який міг здавлювати вени, звужувати просвіт та деформувати досліджувані судини. Виявлялася дистро- фія гладких м'язових клітин, ендотеліоцитів та місцями десквамація останніх. Деякі ендотеліоцити та гладкі міоцити були з явищами набряку, межі між ними нечіткі, частина клітин збільшена у розмірах, дистрофічно і некробіотично змінені. При декомпенсації легеневого серця описані вище структурні зміни вен були виражені у більшому ступені. Переважна більшість венозних судин розширені, переповнені форменими елементами крові, з явищами стазу, що свідчило про виражене порушення їх дренажної функції [1]. Венули при цьому нерідко починалися у вигляді ампул, у які впадали розширені, часто повнокровні закапілярні венули у вигляді китиць. Венозний застій у досліджуваних судинах призводив до посилення гіпоксії, дистрофії та некрозів ендотеліоцитів, інфільтративних та склеротичних процесів.

Висновки. Отримані дані свідчать, що пострезекційна легенева артеріальна гіпертензія призводить до виражених структурних змін у венозному руслі сім'яника, що суттєво порушує дренаж венозної крові від вказаного органа, погіршує його трофічне забезпечення та відіграє важливу роль у патоморфогенезі його ураження. Найвираженішим ступінь ремоделювання венозних судин виявився при декомпенсації легеневого серця.

Перспективи подальших досліджень. Детальне всестороннє вивчення цих явищ представляє перспективну проблему з метою їхнього врахування при діагностиці, корекції та профілактиці уражень сім'яників при пострезекційній легеневій артеріальній гіпертензії.

\section{ЛІТЕРАТУРА}

1. Байбаков В. М. Морфофункціональні зміни венозного русла як ланки дренажної системи яєчка при травмуванні судинних анастомозів сім'яного канатика в експерименті / В. М. Байбаков // Клінічна анатомія та оперативна хірургія. - 2011. - Т. 10, № 4. - С. 32-35.

2. Гнатюк М. С. Секреторна активність кардіоміоцитів передсердь при легеневому серці / М. С. Гнатюк, Л. В. Татарчук, О. Б. Ясіновський // Галицький лікарСький вісник. - 2010. - № 2. - С. 46-48.

3. Горальський Л. П. Основи гістологічної техніки і морфофункціональні методи досліджень у нормі та при патології / Л. П. Горальський, В. Т. Хомич, О. І. Кононський. - Житомир : Полісся, 2011. - 288 с.

4. Гржибовский А. И. Сравнение количественных данных двух парных выборок с использованием программного обеспечения Statistica и SPSS: параметрические и непараметрические критерии / А. И. Гржибовский, О. В. Иванов, М. А. Горбатова // Наука и здравоохранение. - 2016. - Т. 3. - С. 5-25.
5. Грицуляк Б. В. Цитологічні зміни в яєчку в умовах блокади крововідтоку від нього в експерименті / Б. В. Грицуляк, О. Я. Глодан // Вісник Прикарпатського національного університету ім. В. Стефаника. Серія Біологія. - 2011. - Вип. XV. - С. 201-204.

6. Жаринова В. Ю. Эндотелиальная дисфункция как мультидисциплинарная проблема / В. Ю. Жаринова // Кровообіг і гомеостаз. - 2015. - № 1-2. - С. 9-14.

7. Резников О. Г. Загальні етичні принципи експериментів на тваринах // Ендокринологія. - 2003. - Т. 8, № 1. - С. $142-145$.

8. Саркисов Д. С. Структурные основы адаптации и компенсации нарушенных функций / Д. С. Саркисов. М. : Медицина, 1992. -448 с.

9. Татарчук Л. В. Особливості структурно-функціональних змін в артеріях шлуночків серця при пострезекційній легеневій гіпертензії / Л. В. Татарчук // Медична хімія. - 2012. - Т. 14, № 3 (52). - С. 89-93. 
Огляди літератури, оригінальні дослідження, погляд на проблему, випадок з практики, короткі повідомлення REFERENCES

1. Baybakov, V.M. (2011). Morfofunktsionalni zminy venoznoho rusla yak lanky drenazhnoi systemy yaiechka pry travmuvanni sudynnykh anastomoziv simyanoho kanatyka $v$ eksperymenti [Morphofunctional changes of the venous bed as the links of the testicular drainage system in trauma of the vascular anastomoses of the spermatic cord in the experiment]. Klinichna anatomiia ta operatyvna khirurhiia - Clinical Anatomy and Operative Surgery, 10, 432-435 [in Ukrainian].

2. Hnatiuk, M.S., Tatarchuk, L.V., \& Yasinovskyi, O.B. (2010). Sekretorna aktyvnist kardiomiotsytiv peredserd pry lehenevomu sertsi [Secretory activity of atrial cardiomyocytes at cor pulmonale]. Halytskyi medychnyi visnyk Galician Medical Bulletin, 2, 46-48 [in Ukrainian].

3. Goralsky, L.P., Khomych, V.T., \& Kononsky, O.I. (2011). Osnovy histolohichnoi tekhniky i morfofunktsionalni metody doslidzen u normi ta pry patolohii [Fundamentals of histological technique and morphofunctional research methods in normal and pathology]. Zhytomyr: Polissia [in Ukrainian].

4. Grzhibovsky, A.I., Ivanov, O.B., \& Gorbatova, M.A. (2016). Sravneniye kolichestvennykh dannykh dvukh parnykh vyborok s ispolzovaniem programmnogo obespecheniya Statistica i SPSS: parametricheskiye i neparametricheskiye kriterii [Comparison of quantitative data of two pair samples using Statistica and SPSS software: parametric and nonparametric criteria]. Nauka i zdravookhranniyeScience and Health, 3, 5-25 [in Russian].

5. Hrytsulyak, B.V., \& Hlodan, O.Ya. (2011). Tsytolohichni zminy $v$ yaiechku $v$ umovakh blokady krovovidtoku vid nioho v eksperymenti [Cytologic changes in the testicle under conditions of blockage of blood flow from it in the experiment]. Visnyk Prykarpatskoho universytetu im. V. Stefanyka. Seriia Biolohiia - Bulletin of the Carpathian National University. V. Stefanik. Series Biology, XV, 201-204 [in Ukrainian].

6. Zharinova, V.Yu. (2015). Endotelialnaya disfunktsiya kak multidistsiplenarnaya problema [Endothelial dysfunction as a multidisciplinary problem]. Krovoobih $i$ hemostaz - Blood Circulation and Homeostasis, 21, 2, 9-14 [in Ukrainian].

7. Reznykov, O.H. (2003). Zahalni etychni pryntsypy eksperymentiv na tvarynakh [General ethical principles of experiments on animals]. Endokrynolohiia-Endocrinology, 8, 1, 142-145 [in Ukrainian].

8. Sarkisov, D.S. (1992). Strukturnyie osnovy adaptatsii i kompensatsii narushennykh funktsiy [Structural basis adaptation and compensation damage function]. Moscow: Meditsyna [in Russian].

9. Tatarchuk, L.V. (2012). Osoblyvosti strukturnofunktsionalnykh zmin v arteriiakh shlunochkiv sertsia pry postrezektsiinii lehenevii hipertenzii [Features of structural and functional changes in the arteries of the ventricles in postresection pulmonary hypertension]. Medychna khimiia - Medical Chemistry, 14 (52), 89-93 [in Ukrainian].

\section{ОСОБЕННОСТИ РЕМОДЕЛИРОВАНИЯ ВЕНОЗНОГО РУСЛА СЕМЕННИКОВ ПРИ ПОСТРЕЗЕКЦИОННОЙ ЛЕГОЧНОЙ АРТЕРИАЛЬНОЙ ГИПЕРТЕНЗИИ}

○С. А. Коноваленко

Тернопольский национальный медицинский университет имени И. Я. Горбачевского МОз Украины

РЕЗЮМЕ. Удаление правого или левого легкого может приводить к пострезекционной легочной артериальной гипертензии, венозному застою в органах большого круга кровообращения и структурно-функциональным изменениям в них. Морфологические изменения венозного русла семенников при пострезекционной легочной артериальной гипертензии изучены недостаточно.

Цель-изучить особенности ремоделирования венозного русла семенников при пострезекционной легочной артериальной гипертензии.

Материал и методы. Морфологическими методами исследовано венозное русло семенников 45 лабораторных белых крыс-самцов, которые были поделены на 3 группы. Артериальную легочную гипертензию и легочное сердце моделировали путем выполнения исследуемым животным правосторонней пульмонэктомии. Проводили отдельное взвешивание камер сердца и их планиметрию. На гистологических микропрепаратах из семенников определяли диаметр закапилярных венул, венул, диаметр внешний, диаметр внутренний венозных сосудов, высоту эндотелиоцитов венозных сосудов, диаметр их ядер, ядерно-цитоплазматическое соотношение в этих клетках, относительные объемы поврежденных эндотелиоцитов. Статистическую обработку полученных данных осуществляли в программе Statistica Soft 13.0.

Результаты. Всесторонним анализом морфометрических параметров установлено, что большинство из них в условиях смоделированной патологии выражено менялись. Диаметр закапилярных венул при компенсированном легочном сердце статистически $(p<0,01)$ достоверно увеличился с $(12,82 \pm 0,09)$ мкм до $(13,40 \pm 0,12)$ мкм, то есть на 4,5 \%, а диаметр венул - на 2,3 \% (p<0,05). Аналогично менялись внутренний и внешний диаметры венозных сосудов. Внешний диаметр указанных венозных структур статистически достоверно $(p<0,05)$ вырос почти на $3,1 \%$, а внутренний - на 2,8 \% (р<0,05). Высота эндотелиоцитов венозных сосудов и диаметры их ядер в условиях компенсированного легочного сердца существенно не менялись. Не изменены при этом оказались ядерно-цитоплазматические соотношения в эндотелиоцитах, что свидетельствовало о стабильности клеточного структурного гомеостаза. 
Огляди літератури, оригінальні дослідження, погляд на проблему, випадок з практики, короткі повідомлення

Исследуемые морфометрические параметры венозных сосудов при декомпенсированном легочном сердце менялись более выражено. Так, диаметр закапилярных венул в указанных экспериментальных условиях с выраженной статистически достоверной разницей $(p<0,001)$ увеличился на $19,1 \%$. Аналогичной структурной перестройке при этом подверглись также диаметры венул, которые выросли с $(26,96 \pm 0,18)$ мкм до $(32,84 \pm 0,21)$ мкм, то есть на 22,2 \% ( $<0,001)$. Увеличенными в данных условиях опыта оказались также внешние и внутренние диаметры вен. При этом указанный внешний параметр венозных сосудов статистически достоверно $(p<0,001)$ вырос на $18,5 \%$, а внутренний диаметр - на 22,3 \% ( $<<0,001)$. Обнаруженное ремоделирование венозных сосудов приводило к истончению их стенок. Светооптически морфологические изменения структур доминировали при декомпенсации легочного сердца.

Вывод. Полученные данные свидетельствуют, что пострезекционная легочная артериальная гипертензия приводит к выраженным структурным изменениям в венозном русле семенника, что существенно нарушает дренаж венозной крови от указанного органа, ухудшает его трофическое обеспечение и играет важную роль в патоморфогенезе его поражения. Наиболее выраженной степень ремоделирования венозных сосудов оказалась при декомпенсации легочного сердца.

КЛючЕВЫЕ СЛОВА: легочная гипертензия; семенники; венозное русло.

\section{FEATURES OF REMODELING OF THE VENOUS FLOW OF THE TESTICLES AT POSTRESECTION PULMONARY ARTERIAL HYPERTENSION}

\section{Horbachevsky Ternopil National Medical University}

\section{S. O. Konovalenko}

SUMMARY. Removal of the right or left lung can lead to postresection pulmonary arterial hypertension, venous stasis in the circulatory system and structural and functional changes in them. Morphological changes of the venous bed of the testes in postresection pulmonary arterial hypertension are insufficiently studied.

The aim - to study the features of remodeling of the venous flow of the testicles in postresection pulmonary arterial hypertension.

Material and Methods. Morphological methods were used to study the venous flow of the testicles of 45 laboratory white male rats, which were divided into 3 groups. Pulmonary arterial hypertension and pulmonary heart were modeled by performing right-sided pulmonectomy in experimental animals. Separate weighing of heart chambers and their planimetry was performed. On histological micronutrients from testicles the diameter of capillary venules, venules, diameter of external vessels, diameter of internal of venous vessels, height of endotheliocytes of venous vessels, diameter of their nuclei, cytoplasmic ratios in these cells, the relative volumes of damaged endothelial cells were determined Program analysis of the obtained data was performed in the program Statistica Soft 13.0.

Results. A comprehensive analysis of morphometric parameters revealed that most of them in the simulated pathology changed markedly. Thus, the diameter of the capillary venules in the compensated pulmonary heart statistically $(p<0.01)$ significantly increased from $(12.82 \pm 0.09) \mu \mathrm{m}$ to $(13.40 \pm 0.12) \mu \mathrm{m}$, ie by $4.5 \%$, and the diameter of the venules is $2.3 \%(p<0.05)$. The inner and outer diameters of the venous vessels changed similarly. The outer diameter of these venous structures statistically significantly $(p<0.05)$ increased by almost $3.1 \%$, and the inner - by $2.8 \%(p<0.05)$. The height of endothelial cells of venous vessels, the diameters of their nuclei in the conditions of compensated pulmonary heart did not change significantly. Nuclear-cytoplasmic relations in endothelial cells were not changed, which indicated the stability of cellular structural homeostasis.

The studied morphometric parameters of venous vessels in decompensated pulmonary heart changed more markedly. Thus, the diameter of the capillary venules in these experimental conditions with a pronounced statistically significant difference $(p<0.001)$ increased by $19.1 \%$. The diameters of venules, which increased from $(26.96 \pm 0.18) \mu \mathrm{m}$ to $(32.84 \pm 0.21) \mu \mathrm{m}$, ie by $22.2 \%(p<0.001)$, also underwent a similar structural adjustment. The external and internal diameters of the veins were also increased in these experimental conditions. The specified external parameter of venous vessels statistically significantly $(p<0.001)$ increased by $18.5 \%$, and the inner diameter $-22.3 \%$ ( $<<0.001)$. The detected remodeling of venous vessels led to thinning of their walls. Optically and morphologically changes of structures dominated at decompensation of pulmonary heart.

Conclusion. The obtained data show that postresection pulmonary arterial hypertension leads to pronounced structural changes in the venous line of the testis, which significantly disrupts the drainage of venous blood from this organ, impairs its trophic supply and plays an important role in the pathomorphogenesis of its lesion. The most pronounced degree of remodeling of venous vessels was in the decompensation of the pulmonary heart.

KEY WORDS: pulmonary hypertension; testicles; venous flow. 